UDC 632; DOI 10.18551/rjoas.2022-01.21

\title{
PHYSICOCHEMICAL AND HEAVY METALS CONTENT IN STINGLESS HONEY HETEROTRIGONA ITAMA CULTIVATED FROM SAMARINDA, EAST KALIMANTAN, INDONESIA
}

\author{
Saputra Suroto Hadi, Nurlina Sitti \\ Center for Industrial Research and Standardization, Samarinda, East Kalimantan, Indonesia \\ ${ }^{*}$ E-mail: surotohs.65@gmail.com
}

\begin{abstract}
The quality of honey without stings can be seen from its physical, chemical properties and the absence of heavy metals. The purpose of this study was to evaluate the physicochemical and heavy metals content of Heterotrigona itama stingless honey at a specific location in Samarinda City, East Kalimantan. The research method used a one-factor completely randomized design. To find out the effect of treatment from the location of honey, it was analyzed using ANOVA and the smallest significant difference was at the $5 \%$ level. The results showed that $H$. itama honey from Tanah Merah village cultivated in Samarinda had physical properties favored by Fanelis for $92 \%$ color and $88 \%$ aroma, and $75 \%$ taste for $H$. itama honey from Gunung Lingai Village. Chemical properties of reducing sugar content of $64.37 \%$, sucrose $4.55 \%$, total dissolved solids $69.42 \%$, the highest $\mathrm{pH} 2.86$ and $0.19 \%$ the lowest ash content were obtained from $\mathrm{H}$ itama honey from Gunung Lingai, and the water content was $31,68 \%$ the lowest was for $H$. itama honey from Tanah Merah village. All $H$. itama honey from three cultivated locations in Samarinda did not detect any heavy metals content.
\end{abstract}

\section{KEY WORDS}

Chemical properties, $H$. itama, heavy metals, physical properties.

Broadly speaking, honey bee stings can be divided into two types, namely stinging honey bees and stingless honey bees. There are many types of stingless honey bees (Trigona spp.): Trigona itama, Trigona apicalis, Trigona dreschari, Trigona fuscibasis, Trigona fuscobalteata, Trigona onsica, Trigona laeviceps, Trigona terminata (Syafrizal et al., 2012). Heterotrigona itama and Geniotrigona thoracica are stingless bees from six states on the West Coast of Malaysia (Selvaraju et al., 2019). Heterotrigona itama and Trigona binghami are from Sarawak Malaysia (Wong et al., 2019). The Heterotrigona itama bee, also known as Kululut, is a species of stingless bee in Malaysia, Teluk Intan Malaysia (Rahim et al., 2018; Kek et al., 2017). Heterotrigona itama spp from coastal areas in Kelantan and Terengganu Malaysia (Hasali et al., 2018).

T. itama or Heterotrigona itama are mostly cultivated in East Kalimantan such as Sangatta, Samarinda, Kutai Kartanegara, Balikpapan, North Panajam Paser, Paser and Tarakan for North Kalimantan (Saputra et al., 2019; Syafrizal et al., 2020). The results of Trigona spp cultivation can be in the form of honey, pollen and propolis from honey bee nests. The main product of Trigona spp cultivation is honey. In general, honey contains chemical compounds such as water, sugar, sucrose, fructose, carbohydrates, protein, minerals and the possibility of heavy metal content. Heterotrigona itama or Trigona itama originating from five regions in East Kalimantan, Paser, North Panajam Paser, Balikpapan, Kutai Kartanegara and Samarinda (Kampung Rimbawan) contained water chemical compounds $30.80-33.67 \%$, reducing sugar $85-90 \%$, sucrose $1.82-4.57 \%$, non-detection heavy metal (nd)-0.01 mg/L (Saputra et al., 2019). How is the physicochemistry and heavy metal content of Heterotiigoan itama stingless honey found in several specific locations in Samarinda City, East Kalimantan. The purpose of this study was to evaluate the physicochemical and heavy metal content of Heterotrigona itama stingless honey at a specific location in Samarinda City, East Kalimantan. 


\section{METHODS OF RESEARCH}

H. itama honey was obtained from cultivation in three locations, namely Tanah Merah Village, Gunung Lingai Village and Lubuk Sawah Village, North Samarinda District, Samarinda City, East Kalimantan. Honey obtained from the cultivation site is packaged in plastic bottles and then distributed to the laboratory for analysis. Several parameters were analyzed by chemical compounds and heavy metal content in $\mathrm{H}$. itama honey in the form of reducing sugar content, sucrose content, total dissolved solids, $\mathrm{pH}$, water content, ash content and heavy metals $\mathrm{Pb}, \mathrm{Cd}, \mathrm{Hg}$, As. The experimental design used in this study was a one-factor completely randomized design, namely the origin of the honey sample as a treatment. To find out the effect of the treatment, it was analyzed using ANOVA and if there was an effect, the analysis continued with the smallest significant difference at the $5 \%$ level. Parameters analyzed were reducing sugar content, sucrose content, total dissolved solids, $\mathrm{pH}$, water content, ash content and. The average value of heavy metal analysis results was compared between treatments.

\section{RESULTS AND DISCUSSION}

Physical properties of Heterotrigona itama honey from three cultivated locations in Samarinda are shown in Table 1.

Table 1 - The results of the analysis of the physical properties of $H$. itama honey

\begin{tabular}{lllll}
\hline Origin location & \multicolumn{2}{l}{ Parameters $(\%)$} & SNI:8664:2018 \\
& Color & Aroma & Taste & \\
\hline Lubuk Sawah Village & 76 & 80 & 68 & Honey special color \\
Tanah Merah Village & 92 & 88 & 60 & Honey special aroma \\
Gunung Lingai Village & 88 & 60 & 75 & Honey special taste \\
\hline
\end{tabular}

Color, aroma and taste are physical properties of stingless honey which are the requirements of SNI: 8664: 2018 (BSN, 2018) with honey characteristics. The results show (Table 1) that 25 respondents stated that $H$. itama honey from three cultivated locations in Samarinda, both color (76-92\%), aroma (60-88\%) and taste (60-75\%) were typical of honey (Table 1). SNI: 8664: 2018). Saputra et al (2019) Physical properties such as color, aroma and taste of $\mathrm{H}$. itama honey from five cultivated areas in East Kalimantan ranged from 52$100 \%$ (color), $70-92 \%$ (aroma) and $56-88 \%$ (taste). This difference is caused by variations in the source of flower essence obtained by bees (Saputra et al., 2021).

Physical properties are components to indicate the quality of honey. The dark and light color of honey is influenced by the source of the nectar obtained. According to Suranto (2007), the light color of honey is preferred by consumers. Heterotrigona itama stingless bee honey has strong color sensory characteristics. Ferreira et al (2009) and Souza et al (2013) stated that monoflorate honey has a sensory (aromatic) taste for stingless honey (Stinglees bee). In addition, according to Ferreira et al (2009) physical sensory properties (aroma) in honey vary depending on plant origin, ripening time, weather and storage conditions. The taste of stingless honey is different from that of stinging honey. A slightly sweet sour taste (typical of honey) is a characteristic of $H$. itama honey with a pH range of 2.77-3.20 (Saputra et al., 2019). Honey without a sting has a distinctive taste (Compos et al., 2010; Sousa et al., 2013). The characteristic presence of stingless honey is due to the source of the nectar, the source of the flowers obtained (Belay et al., 2015; Silvano et al., 2014).

Some of the chemical properties of H.itama stingless honey in this study were reducing sugar content, sucrose content, total dissolved solids, $\mathrm{pH}$, water content and ash content. In addition, an analysis of the metal content contained in $\mathrm{H}$. itama. This chemical analysis can determine the quality of a honey such as reducing sugar content, sucrose content, total dissolved solids, $\mathrm{pH}$, water content and ash content. The results of chemical analysis in this study are as shown in Table 2. 
Table 2 - Chemical Parameters of $H$. itama Stingless Honey

\begin{tabular}{lllllll}
\hline Origin location & Parameters & & & & \\
\cline { 2 - 7 } & $\begin{array}{l}\text { Reducing } \\
\text { sugar content } \\
(\%)\end{array}$ & $\begin{array}{l}\text { Sucrose } \\
\text { content } \\
(\%)\end{array}$ & $\begin{array}{l}\text { Total } \\
\text { dissolved } \\
\text { solids ( }{ }^{\circ} \text { Brig) }\end{array}$ & pH & $\begin{array}{l}\text { Water } \\
\text { content } \\
(\%)\end{array}$ & $\begin{array}{l}\text { Ash } \\
\text { content } \\
(\%)\end{array}$ \\
\hline Lubuk Sawah Village & $58,38^{\mathrm{a}}$ & $3,22^{\mathrm{a}}$ & $68,17^{\mathrm{a}}$ & 2,85 & $31,80^{\mathrm{a}}$ & $0,26^{\mathrm{a}}$ \\
Tanah Merah Village & $61,54^{\mathrm{b}}$ & $3,62^{\mathrm{b}}$ & $69,21^{\mathrm{b}}$ & 2,75 & $31,68^{\mathrm{b}}$ & $0,22^{\mathrm{b}}$ \\
Gunung Lingai Village & $64,37^{\mathrm{c}}$ & $4,55^{\mathrm{c}}$ & $69,42^{\mathrm{b}}$ & 2,86 & $31,85^{\mathrm{a}}$ & $0,19^{\mathrm{c}}$ \\
\hline
\end{tabular}

The results of the analysis of variance from the location of $H$. Itama stingless honey showed a significant effect at the $5 \%$ level for the parameters of reducing sugar, sucrose content, total dissolved solids, water content, ash content and $\mathrm{pH}$ had no significant effect. The results of the further test of the smallest significant difference at the $5 \%$ level can be seen in table 2 where the numbers followed by the same letter show no significant difference.

The average value of reducing sugar content in $H$. itama honey from three cultivated locations in Samarinda showed a difference where the highest value of reducing sugar content was $64.37 \%$ from Gunung Lingai Village, followed by $61.54 \%$ from Tanah Merah Village and $58,38 \%$ of the Lubuk Sawah Village. The difference in the levels of reducing sugar from the three locations of origin of the honey is thought to be due to the different types of flower extract sources obtained. The results of the study of Saputra et al (2019) levels of reducing sugar $\mathrm{H}$. itama from five cultivated areas in East Kalimantan, namely Kutai Kartanegara (51.58\%), Samarinda Kampung Rimbawan (55.37\%), Paser (59.56\%), Balikpapan (60.93\%) and 63.68\% from Panajam Paser Utara. Saputra et al (2021). states that different sources of flower essence will produce different reducing sugars found in honey from five regions in East Kalimantan. If viewed from the quality standard of the Indonesian National Standard SNI 8664:2018 (BSN, 2018) the minimum limit is 55\%, the reducing sugar in $H$. itama honey to the three regions in Samarinda meets the requirements of SNI 8664:2018.

The average value of sucrose content in $H$. itama honey from the three cultivation locations in Samarinda showed different where the highest sucrose content value was in Gunung Lingai Village 4.55\%, followed by Tanah Merah Village 3.62\% and Lubuk Paddy Village $3.22 \%$. The sucrose content of the three cultivated locations in Samarinda still meets the quality standard requirements of SNI: 8664: 2018 (BSN, 2018) of a maximum of 5\%. The results of the study of Saputra et al (2019) stated that the sucrose content of $H$. itama honey from five cultivated areas in East Kalimantan also contained differences, namely Kutai Kartanegara 1.82\%, Samarinda (Kampung Rimbawan) $2.79 \%$, Paser Regency $3.82 \%$, Panajam Paser Utara 4.14\% and Balikpapan 4.57\%. The level of sucrose in stingless honey is indicated to be small. This is also from the results of Chuttong et al (2016) stated that out of 28 samples of stingless honey, only five stingless honeys were detected to contain sucrose. Sucrose content of $H$. itama from Sarawak, Danga Dap. of $0.04 \pm 0.30 \mathrm{~g} / 100 \mathrm{~g}$ (Wong et al., 2018).

The total dissolved solids of $H$. itama honey as shown in table 2 shows that there is a difference between the location of cultivation in Lubuk Sawah Village (68.17\%) and honey from Tanah Merah Village (69.21\%) and Gunung Lingai Village (69.42). This difference is thought to be due to the taking of different types of pollen sources. The range of total dissolved solids content in $\mathrm{H}$. itama honey from three cultivated locations in Samarinda was $68.17 \%-69.42 \%$. Saputra et al (2019) stated that the total dissolved solids content of $H$. itama honey cultivated from five regions of East Kalimantan was $67.23 \%-69.77 \%$. This vaue is similar to the total dissolved solids content in cultivated honey from three locations in Samarinda. Total dissolved solids is a combined measure of organic and inorganic substances contained in honey, ionized and micro molecules or suspended form (Khalil et al., 2012; Moniruzzaman et al, (2013). The variability of the total dissolved solids content in honey can be caused by the harvesting process, maintenance techniques and pollen obtained by bees (Fiolia et al., 2007).

The $\mathrm{pH}$ levels of honey from three cultivation locations did not differ from each other with a range of values from 2.75 to 2.86 (Table 2). As with the results of research by Saputra 
et al (2019) stated that the $\mathrm{pH}$ of $\mathrm{H}$. itama honey in five cultivated areas in East Kalimantan ranged from 2.77-3.20. $\mathrm{H}$. itama honey has a low $\mathrm{pH}$ tendency. Honey contains gluconic acid which is the result of the breakdown of glucose by enzymes. There are other types of acids found in honey are acetic, butyric, formic, gluconic, lactic, malic, maleic, oxalic, pyroglutamic, citric, succinic, glycolic, ketoglutarate, pyruvate, 3-phosphoglycorate, -glycerophaosphate and glucosephosphate acids (Suarez et al., 2010). The level of $\mathrm{pH}$ in honey can be useful in the resistance and stability of honey to attack microorganisms (Saputra et al., 2012).

The moisture content of Heterotrigona itama honey from three cultivated locations in Samarinda showed that the red soil honey content was different from the water content of honey from Lubuk Sawah Village and Gunung Lingai Village at the 5\% level. The range of water content of the three cultivated locations was $31.68 \%-31.85 \%$. As the results of research by Saputra et al (2019) that the moisture content of $H$. itama honey from five cultivated areas in East Kalimantan is above 30\%, namely $30.80-31.67 \%$. That East Kalimantan is a tropical rain forest area. Fitriani et al (2014) stated that the water content of honey originating from Indonesia is high this is due to the very high humidity level of the tropics, namely 60\% -80\%. In addition, honey has hygroscopic properties (Buba et al., 2013).

The ash content of $H$. itama honey from the three cultivated locations in Samarinda differed from one another (table 2). The ash content of the honey is still below SNI $8664: 2018$ with a maximum of $0.5 \%$ (BSN, 2018). Saputra et al (2019) stated that the ash content of $H$. itama cultivated from five regions in East Kalimantan ranged from $0.17-0.35 \%$, where this ash content also still met the requirements of SNI 8664:2018 of a maximum of $0.5 \%$ (BSN, 2018). The ash content of $H$. itama from Malaysia is $0.22-0.41 \%$ (Bakar et al., 2017; Kek et al., 2017; Rahim et al., 2018). The factor that affects the ash content is the activity of foraging for honey in different regions (El Sohaimy et al., 2015).

The data from the analysis of heavy metals in $H$ honey are as shown in Table 3.

Table 3 - Results of analysis of heavy metal content of $H$. itama honey

\begin{tabular}{|c|c|c|c|c|c|}
\hline \multirow[t]{2}{*}{ Origin location } & \multicolumn{4}{|c|}{ Heavy metals (mg/L) } & \multirow{2}{*}{$\begin{array}{l}\mathrm{SNI}: 8664.2018(\mathrm{mg} / \mathrm{kg}) \\
\mathrm{Pb}=1,0\end{array}$} \\
\hline & $\mathrm{Pb}$ & $\mathrm{Cd}$ & $\mathrm{Hg}$ & As & \\
\hline Lubuk Sawah Village & nd & nd & nd & nd & $\mathrm{Cd}=0,2$ \\
\hline Tanah Merah Village & nd & nd & nd & nd & $\mathrm{Hg}=0,03$ \\
\hline Gunung Lingai Village & nd & nd & nd & nd & $A s=1,0$ \\
\hline
\end{tabular}

Description: non detected (nd).

In general, heavy metals in $H$. itama honey from three cultivated locations in Samarinda were not detected or contained no heavy metals (table 3 ). The absence of heavy metals in honey can be categorized as safe for consumption SNI: 8664:2018 (BSN, 2018). The results of the study of Saputra et al (2019) stated that in general the levels of heavy metals in $\mathrm{H}$. itama honey from five cultivated areas in East Kalimantan ranged from nondetection to $-0.01 \mathrm{mg} / \mathrm{L}$ but met SNI: 8664: 2018 (BSN, 2018). According to (Vogel, 1990) the characteristics of $\mathrm{Pb}$ metal are bluish-gray in color, have a fairly high density, are very soft and easily melt in concentrated $\mathrm{HNO}_{3}$ solution, slightly soluble in $\mathrm{HCl}$ and $\mathrm{H}_{3} \mathrm{PO}_{4}$. Darmono (1995) stated that cadmium is absorbed by plants from the soil through the roots and circulated to the plant parts. Regarding mercury, Irianti and Tanti (2018) stated that inorganic mercury is commonly used for disinfectants. Rindoni et al (2020) stated that arsenic at low concentrations is found in soil, water, food and air.

\section{CONCLUSION}

Based on the results of the study, it can be concluded that the physical properties of $H$. itama honey from the three cultivated locations in Samarinda were assessed by the typical honey fanelis, namely color $76-92 \%$, aroma $60-88 \%$ and taste $60-75 \%$. Chemical properties have reducing sugar content of $76-92 \%$, sucrose content of $3.22-4.55 \%$, total dissolved solids $68.17-69.42 \%$, pH $2.75-2.86$, water content $31.68-31.85 \%$ and $0.19-0.26 \%$ ash content. Heavy metal content was not detected. 


\section{REFERENCES}

1. Apriantono, A., Fardiaz., D., Puspitasari, N.L., Sedarnawati, Budiyanto, S (1989). Analisis Pangan, IPB Press, Bogor.

2. Bakar M.F.A., Sanusi, S.B., Bakar, F.I.A., Cong, O.J., Mian, Z (2017). Physicochemical and Antioxidant Potential of Raw Unprocessed Honey from Malaysian Stingless Bee, Pak J Nur, 16 (11): 888-894.

3. Belay, A., Solomon, W.K., Bultossa, G., Adgaba, N., Melaku, S (2015). Botanical Origin, Colour, Granulation, And Sensory Properties of The Harenna Forest Honey, Bale, Ethiopia, Food Chemistry, 167: 213-219.

4. BSN (1998). Standar Nasional Indonesia (SNI:01-2896), Cara Uji Cemaran Logam dalam Makanan, Jakarta.

5. BSN (1998). Standar Nasional Indonesia (SNI:01-4866), Cara Uji Cemaran Arsen dalam Makanan, Jakarta.

6. BSN, (2018). Standar Nasional Indonesia (SNI:8664) Madu, Jakarta.

7. Buba, F., Gidado, A., and Shugaba. A (2013). Analysis Of Biochemical Composition of Honey Samples From North-Eat Nigeria Biochemical and Analytical Biochemistry, $3(2): 1-7$.

8. Campos, F.S., Gois, G.C., Carneiro, G.G (2010). PhysicoChemical Parameters of The Honey of Stingless Bee Melipona Scutellaris Produced in the Paraíba, Zootecnia, 7: 186-190.

9. Chuttong, B., Chanbang, Y., Sringarm, K. \& Burgett, M (2016). Physicochemical profiles of stingless bee (Apidae: Meliponini) honey from South East Asia (Thailand). Food Chemistry 192: 149-155.

10. Darmono (1995). Logam dalam Sistem Biologi Mahluk Hidup, Penerbit Universitas Indonesia (UI Press), Jakarta.

11. El Sohaimy, S.A., Masry, S.H.D., Shehata, M.G (2015). Physicochemical Characteristics of Honey from Different Origins. Annals of Agricultural Sciences, 60: 279-287.

12. Fatriani, A.A. Rezekiah, A. Fitriani (2014). Analisa Usaha Lebah Madu Hutan dan Kualitasnya. Jurnal Hutan Tropis, 2 (1):77-81.

13. Ferreira, I.C.F.R., Aires, E., Barreira, J.C.E., Estevinho, L.M (2009). Antioxidant Activity of Portuguese Honey Samples: Different Contributions of the Entire Honey and Phenolic Extract. Food Chemistry, 114: 1438-144.

14. Hasali, N.H., Zamri, A.I., Lani, M.N., Mubarak, A., Ahmad, F., Chilek, T.Z.T (2018). Physico-Chemical Analysis And Antibacterial Activity Of Raw Honey Of Stingless Bee Farmed In Coastal Areas In Kelantan And Terengganu. Malays.Appl,Biol. 47(4): 145-151.

15. Irianti dan Tanti (2018). Logam Berat dan Kesehatan. Yogyakarta.

16. Kek, S.P., Chin, N.L., Yusof, Y.A., Tan, S.W, Chua, L.S (2017). Classification of entomological origin of honey based on its physicochemical and antioxidant properties. International Journal of Food Properties. 20 (53): 52727-52738.

17. Selvaraju, K., Vikram, K., Soon, P., Krishna, J.M., Mohammed, K.T (2019). A. Melissopalynological, physicochemical and antioxidant properties of honey from West Coast of Malaysia. J Food Sci Technol. 56 (5): 2508-2521.

18. Finola, M.S., Lasagno, M.C., Marioli,. J.M (2007). Microbiological and Chemical Characterization of Honeys From Central Argentina. Food Chemistry. 100 (4): 16491653.

19. Khalil, Md.I., Moniruzzaman, M., La đ Boukraa â, Benhanifia, M., Islam, Md.A., Islam, Md.N., Sulaiman S.A., and Gan. S.H (2012). Physicochemical and Antioxidant Properties of Algenan Honey Molecules, 17 (9): 11199-11215.

20. Moniruzzaman, M., Khalil, M.I., Sulaiman, S.A., Gan. S.H (2013). Physicochemical and Antioxidant Properties of Malaysian Honeys Produced by Apis cerana, Apis dorsata, and Apis mellifera. BMC Complement Altern Med. 13: 43.

21. Rahim, N.S., Hussain, W.N.W., Mohamad, S., Ariffin, Z.Z (2018). Physicochemical analysis, free radical scavenging activity and anti-acetylcholinesterase activity of stingless bee honey. International Journal of Engineering \& technology. 7 (4): 5057-5060. 
22. Ridoni, R., Radam, R., Fatriani, 2020. Analisis Kualitas Madu Kelulut (Trigona sp.) dari Desa Mangkauk Kecamatan Pengaron Kabupaten Banjar, Jurnal Sylva Scienteae, 03 (2): 346-355.

23. Suarez. J.M.A., Tulipani, S., Romandini, S., Bertoli, E., Battino, M (2010). Contribution of Honey in Nutrition and Human Health: A. Review, Mediterrenian J. Nutr. Metabolisme, (3): 15-23.

24. Saputra. A.A (2012). Pembuatan Madu Kering Dari Kristal Madu Dengan Kasein Sebagai Bahan Anti Caking, Skripsi, Universitas Indonesia, Jakarta.

25. Saputra., S.H., Saragih, B., Kusuma, I.W., Arung, E.T (2019). The Physicochemistry of Stingless Bees Honey (Heterotrigona itama) from Different Meliponiculure Areas in East Kalimantan, Indonesia. Procceding of the Symposium on Tropical Studies (JSTS, 2019). Advances in Biological Science Research, volume 11. Atlantis Press.

26. Saputra, S.H., Saragih, B., Kusuma, I.W., Arung, E.T (2019). Antioxidant and antibacterial screening of honey of Hiterotrigona itama collected from different meliponiculture areas in East Kalimantan. Nusantara Biosceince. Vol. 13 (2): 232-237.

27. Silvano, M.F., Varela, M.S., Palacio, M.A., Ruffinengo, S., Yamul, D.K (2014). Physicochemical parameters and Sensory Properties of Honeys from Buenos Aires Region. Food Chemistry, 152: 500-507.

28. Sousa, J.M.B., Aquino, I.D.S., Magnani, M., de Albuquerque, J.R., Santos, G., dos Santos., de Souza, L.S (2013). Physicochemical Aspects and Sensory Profile of Stingless Bee Honeys from Serido Region, State of Rio Grande do Norte, Brazil. Semina: Ciencias Agrarias, 34: 1763- 1772.

29. Sudarmadji, S., Haryono, B., Suhardi (2010). Prosedur Analisa Bahan Makanan dan Pertanian, Liberty, Yogyakarta.

30. Syafrizal , Bratawinata, A. A., Sila, M., Marji, D (2012). Jenis Lebah Kelulut (Trigona spp.) Di Hutan Pendidikan Lempake. Mulawarman Scientific. 11 (1):11-18.

31. Syafrizal , Ramadhan, R., Kusuma, I.W., Egra, S., Shimizu, K., Kanzaki, M., Arung, E.T (2020). Diversity and honey properties of stingless bees from meliponiculture in East and North Kalimantan, Indonesia. Biodiversity. 21 (10): 4623-4630.

32. Wong, P., Hii, S.L., Koh, C.C., Moh, T.S.Y., Gindi, S.R. and Wong, W.P.M (2018). Physicochemical and Proximate Analysis of Heterotrigona itama Honey from Inland and Coastal Regions of Sarawak. ASM Sc. J., 13 (4): 36-44.

33. Wong, P., Ling, H.S., Chung, K.C., Yau, T.M.S., Gindi, S.R.A (2019). Chemical Analysis on the Honey of Heterotrigona itama and Tetrigona binghami from Sarawak, Malaysia. Sains Malaysiana. 48 (8):1635-1642.

34. Vogel, A, I (1990). Kimia Analisis Kualitatif Anorganik: Penerjemah L. Soetiono, Edisi Kelima Bagian I, PT. Kalman Media Pustaka, Jakarta, 239- 294. 